\section{An analysis of the relationship between learning satisfaction and academic achievement of non-traditional learners in Singapore}

\author{
Khiat, Henry $\bowtie$ \\ SIM University, Singapore (henrykhiat@unisim.edu.sg)
}

Received: 12 September 2013

Available Online: 10 November 2013

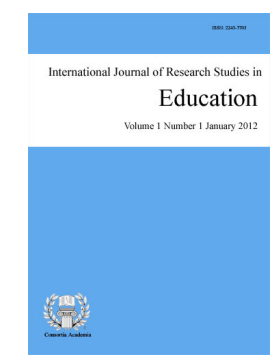

ISSN: 2243-7703 Online ISSN: 2243-7711

Accepted: 31 October 2013

OPEN ACCESS

\title{
Abstract
}

This study investigated the relationship between the learning satisfaction and academic achievement of non-traditional learners in Singapore. Data were collected from 880 students through a component of the student evaluation exercise in a Singapore university in 2011. A mixed-methods approach was adopted in the analysis. Spearman's rho coefficient stated that there is a weak but significant correlation between academic achievement and learning satisfaction. Coding and categorization of the qualitative data explained that the types of learning satisfaction can be derived from three categories as perceived by the respondents: a) Instructors; b) Learning resources and c) Non learning related factors. Pearson Chi-square test for independence further indicated that there is a significant association between the level of learning satisfaction and the types of learning satisfaction. Understanding how learning satisfaction originated from non-traditional learners in the case university is important as the case university can focus on addressing them as a starting point to improve their learning satisfaction which can impact on student learning. At the same time, from a research viewpoint, this study can contribute to the existing relevant literature related to learning satisfaction of non-traditional learners.

Keywords: academic achievement; inferential statistics; learning satisfaction; non-traditional learner; Singapore 


\section{An analysis of the relationship between learning satisfaction and academic achievement of non-traditional learners in Singapore}

\section{Introduction}

In tertiary education, there are generally two types of learners, the traditional ones and the non-traditional ones. A traditional student is usually one who goes direct into university for full time study after graduating from the pre-tertiary institution. On the contrary, a non-traditional student is typically an adult above 24 years old who is juggling different roles as a student, worker, spouse and/or parent and is at least one year absent from studying in a learning institution (Howell, 2001; Vander Zander, 2000). In Singapore, traditional and non-traditional learners can pursue their studies in local public funded universities or private educational institutions that offer degrees from overseas universities. Public funded universities are regulated by the Ministry of Education, while private educational institutions are regulated by the Council for Private Education. Specifically, for non-traditional learners, they generally take government subsidized part time degrees in the three public funded universities (National University of Singapore, Nanyang Technological University, and Singapore Management University) and Singapore's only private university, SIM University.

Learner satisfaction of both traditional and non-traditional learners is an important consideration for tertiary educational institutions. Learner satisfaction is a learner's subjective evaluation of the services' performance provided by a learning institution (Kotler, Lane, Koshy \& Jha, 2009; Sweeney \& Ingram, 2001; Tough, 1982). A learner will feel a certain level of learning satisfaction, depending on whether the actualisation of an educational service used by him or her, is equivalent to, surpasses or does not meet his or her expectation set (Martin, 1988). In terms of learning effectiveness, learner satisfaction is an indirect indicator of the effectiveness of the curriculum (including the quality of instruction) as compared to direct ones such as examination results, project works, internships etc. (Jamelske, 2009; Marsh \& Roche, 1997; Witowski, 2008).

The level of reciprocity and empathy of university personnel towards students can also affect the level of learner satisfaction (Elliot \& Shin, 2002; Emery, Kramer \& Tian, 2001; Guolla, 1999; Umbach \& Porter, 2002). This is especially distinct in the domain of adult education where non-traditional learners see excellent customer service in terms of weekend or evening administration or advisory services, streamlined services, strong faculty learning support etc. as important in improving their learning satisfaction (Brown, 2004; Hadfield, 2003). Time, family and finance-related factors can affect non-traditional learners' learning satisfaction (Malin, Bray, Doughterty \& Skinner, 1980). On the other hand, the friendliness and accessibility of the campus environment and facilities can affect learner satisfaction (Guolla, 1999; Wiers-Jenssen, Stensaker \& Grogaard, 2002). In terms of social interaction, an interesting and exciting campus life tends to improve learner satisfaction (Gray, Fam \& Llanes, 2003; Spady, 1970). Thus, a students' satisfaction in learning can be multi-dimensional - academic, personal, social and physical. In this regard, educational services can be related directly and indirectly to the learning process undergone by the learner in the educational institution. Thus, the influencing factors of a learner's satisfaction can be found beyond the learner's acquisition of knowledge and skills and are also related to the learner's personal, physical and social development (Jamelske, 2009; Wiers-Jenssen, Stensaker \& Grogaard, 2002; Witowski, 2008).

More specifically, these influencing factors can be related to the quality of course delivery and content, quality of assessment, quality of administrative functions, types of facilities and the overall learning experience provided in a learning institution (Aman, 2009; Beqiri, Chase \& Bishka, 2010; Betz, Klingensmith \& Menne, 1970; Calaguas, 2012; Corts, Lounsbury, Saudargas \& Tatum, 2000; Kara, 2004). The experiences that determine the learning satisfaction of traditional learners and non-traditional learners are different (Bontenbal, 2000; Bull \& Kimball, 2000). Compton, Cox, and Laanan (2006), Wei (2007) and Wintre and Yaffe (2000) stated that there may be differences in learning goals, motivation and commitment between non-traditional learners and 
The relationship between learning satisfaction and academic achievement of non-traditional learners

the younger traditional learners. However, little is known about the areas that non-traditional learners are satisfied about in terms of their university experiences (Keith, 2007). In the context of Singapore, learner satisfaction is seldom researched on in tertiary education.

Learner satisfaction has implications on different domains in education at tertiary level. One, understanding learner satisfaction can help tertiary educational institutions to make the necessary adjustment in response to the market needs of their courses and programs (Aldrige \& Rowley, 1998; Elliott \& Shin, 2002; Eyck, Tews \& Ballester, 2009; Özgüngör, 2010; Upcraft \& Schuh, 1996; Witowski, 2008). Two, learner satisfaction can have impact on learning effectiveness. All other factors being equal, a satisfied student is likely to put in more effort in his or her study than an unsatisfied student (Elliott \& Shin, 2002; Jamelske, 2009; Özgüngör, 2010). Similarly, satisfied students would be more motivated to attend classes and are less likely to quit studies (Noel-Levitz, 2009). The level of learning effectiveness would then be translated to the level of academic development or grade achieved by a learner (Centra \& Rock, 1983; Hatcher, Kryter, Prus, \& Fitzgerald, 1992; Pike, 1991; Umbach \& Porter, 2002). However, most studies on relationship between learning satisfaction and academic achievement focused on traditional learners. In the context of Singapore, a search of the literature, though not exhaustive, did not yield such studies that investigated on the non-traditional learners' academic achievement and their learning satisfaction.

In summary, this brief review showed that there are benefits in understanding the types of learning satisfaction non-traditional learners experienced and the relationship between their learning satisfaction and their academic performance. This study focused on the learning satisfaction of non-traditional learners in Singapore. As there is little research on non-traditional learners in the local context, this study can help contribute significantly to the current related literature.

\subsection{Research Question}

The aim of this study is to investigate on the aspects related to learning satisfaction level of non-traditional learners. The research question is: "What are the relationships between non-traditional learner satisfaction level in learning, their academic performance and the identified influencing factors of learning satisfaction?"

\section{Methodology}

Data Source: This study made use of a component of the student evaluation exercise in a Singapore university in 2011. This particular component is related to student satisfaction level in their learning. A sample of 880 respondents was selected in the analysis. The 880 responses were selected based on their availability of qualitative feedback to Qn 4 and Qn 5 from the whole population of the non-traditional learners (about 10,000 students) that did this survey. Responses without feedback in Qn 4 and Qn 5 were not selected as they were not useful in uncovering the factors that affected the students' learning satisfaction and their relationships. The design of the questionnaire items in this component is as below in Table 1.

Table 1

Questionnaire Items

\begin{tabular}{|c|c|c|}
\hline Questionnaire Item & Response & $\begin{array}{c}\text { Number of analyzable } \\
\text { responses* }\end{array}$ \\
\hline $\begin{array}{l}\text { Q1: Had been pleasant/satisfying } \\
\text { Q2: Had been beneficial } \\
\text { Q3: Was positive enough for me to recommend others to go } \\
\text { through }\end{array}$ & $\begin{array}{l}\text { 1: STRONGLY DISAGREE 2: DISAGREE 3: } \\
\text { NEUTRAL 4: AGREE 5: STRONGLY } \\
\text { AGREE }\end{array}$ & 880 \\
\hline $\begin{array}{l}\text { Q4: In what ways could your learning experience be } \\
\text { enhanced/improved? } \\
\text { Q5: What did you like best about your learning experience? }\end{array}$ & OPEN ENDED RESPONSE & $\begin{array}{l}679 \\
673\end{array}$ \\
\hline
\end{tabular}

There are three items in the 5 point Likert scale questionnaire items (1- Strongly disagree, 2-Disagree, 
Khiat, $\mathrm{H}$.

3-Neutral, 4-Agree, 5-Strongly agree):

My overall learning experience

Had been pleasant/satisfying

$>\quad$ Had been beneficial

$>\quad$ Was positive enough for me to recommend others to go through

Qn 1 to Qn 3 had high construct validity in measuring student satisfaction level as they were mentioned in the literature that describe or measure student learning satisfaction (such as Aldrige \& Rowley, 1998; Elliott \& Shin, 2002; Eyck, Tews \& Ballester, 2009; Jamelske, 2009; Noel-Levitz, 2009; Witowski, 2008; Özgüngör, 2010). The reliability of the three items was also high as their combined Cronbach's Alpha is 0.919 (Table 2).

Table 2

Reliability Statistics of Satisfaction Index

\begin{tabular}{ccc}
\hline Cronbach's Alpha & Cronbach's Alpha Based on Standardized Items & N of Items \\
\hline .915 & .919 & 3 \\
\hline
\end{tabular}

The mean of the three items was not used in the statistical tests as the study did not assume that the measurement of each item is an interval scale. The reason was this study did not assume equidistance between each interval of measurement. Therefore, the median of the three items for each respondent was used as the yardstick of the respondents' learning satisfaction. It was known as "Satisfaction Index" in this study.

As Qn 4 and Qn 5 were not compulsory, all respondents would answer at least one of the two questions. In all, there were a total of 679 and 673 responses respectively from the total of 880 students (shown in Table 1). Qn 4 and Qn 5 significantly uncovered the specific factors that determine a non-traditional learner's satisfaction level in learning. Table 3, Table 4 and Figure 1 showed the statistics and distribution of the Satisfaction Index of the 880 respondents respectively. The median and mode of the Satisfaction Index was 4.00.

Table 3

Frequency Table of Satisfaction Index

\begin{tabular}{llllll}
\hline & \multicolumn{2}{c}{ Frequency } & Percent & Valid Percent & $\begin{array}{c}\text { Cumulative } \\
\text { Percent }\end{array}$ \\
\hline Valid & Strongly Unsatisfied & 11 & 1.3 & 1.3 & 1.3 \\
& Unsatisfied & 49 & 5.6 & 5.6 & 6.8 \\
& Neutral & 174 & 19.8 & 19.8 & 26.6 \\
& Satisfied & 502 & 57.0 & 57.0 & 83.6 \\
& Strongly Satisfied & 144 & 16.4 & 16.4 & 100.0 \\
& Total & 880 & 100.0 & 100.0 & \\
\hline
\end{tabular}

Table 4

Statistics of Satisfaction Index

\begin{tabular}{lll}
\hline $\mathrm{N}$ & Valid & 880 \\
& Missing & 0 \\
Median & & 4.0 \\
Mode & & 4.0 \\
Percentiles & 25 & 3.0 \\
& 50 & 4.0 \\
& 75 & 4.0 \\
\hline
\end{tabular}




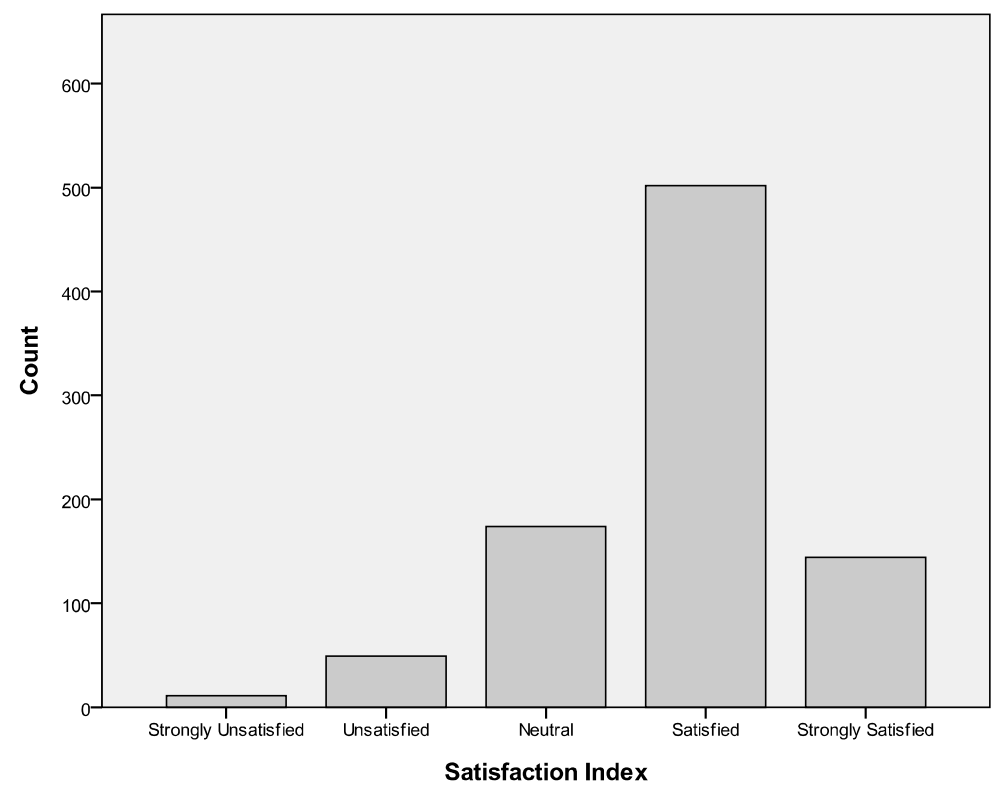

Figure 1. Frequency distribution of satisfaction index

The Cumulative Grade Point Average (CGPA) scores of these 880 students were also retrieved so as to understand the relationship between learning satisfaction and academic achievement. The descriptive statistics of the CGPA of the 880 respondents is in Table 5 and its corresponding histogram is shown in Figure 2.

\section{Table 5}

Summary Statistics of CGPA

\begin{tabular}{llll}
\hline & & Statistic & Std. Error \\
\hline CGPA & Mean & 3.28 & .026 \\
& 95\% Confidence Interval forLower Bound & 3.23 & \\
Mean & 3.33 & \\
5\% Trimmed Mean & 3.31 & \\
Median & 3.35 & \\
Variance & .61 & \\
Std. Deviation & .78 & \\
Minimum & .00 & \\
Maximum & 5.00 & \\
Range & 5.00 & \\
Interquartile Range & 1.03 & \\
Skewness & -.58 & .08 \\
Kurtosis & .55 & .17 \\
\hline
\end{tabular}

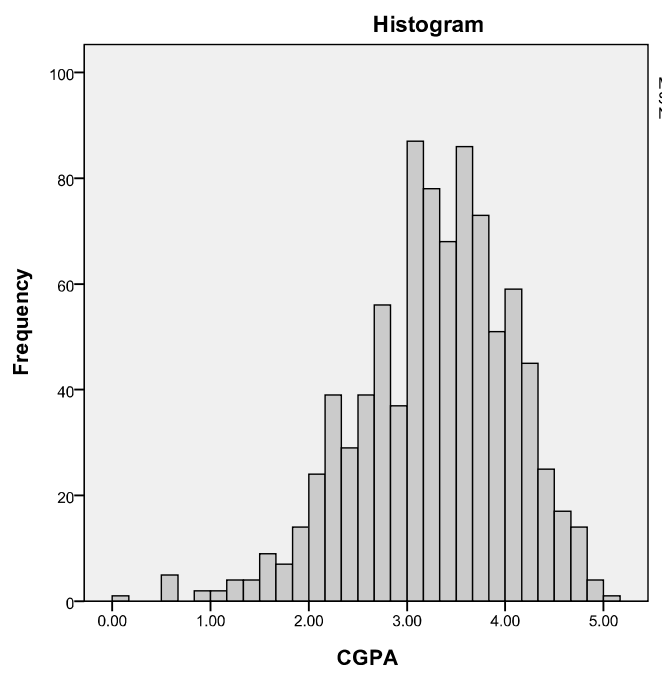

Mean $=3.28$
Std. Dev. $=0.784$

Std. Dev. $=0$
$N=880$

Figure 2. Frequency distribution of CGPA 
Khiat, H.

Kolmogorov-Smirnov Test (Table 6) was significant, indicating that the assumption of normality was violated for the variable CGPA. The visual representation of the histogram (Figure 2) representing the CGPA of the 880 respondents also showed that normality could not be assumed here. Therefore, due to its non-normality and the designation of the variable Satisfaction Index as an ordinal scale, the variable CGPA was also designated as an ordinal scale. This would ensure more rigor in the statistical tests used later in the analysis.

Table 6

Normality Test of CGPA

\begin{tabular}{lllllll}
\hline & \multicolumn{3}{l}{ Kolmogorov-Smirnov } \\
& Statistic & df & Sig. & Statistic & df & Sig. \\
\hline CGPA & .06 & 880 & .000 & .98 & 880 & .000 \\
\hline Note & . Lilliefors Significance Correction & & &
\end{tabular}

In summary, both Satisfaction Index and CGPA were designated as ordinal scales to ensure the underlying assumptions governing the use of the selected statistical tests were not violated.

\subsection{Data Analysis}

SPSS was used in the inferential statistical analysis process and simple categorisation was used in uncovering the different factors that made up learning satisfaction among the respondents. A correlation test was conducted to investigate the relationship between Satisfaction Index and CGPA. Since both variables are designated as ordinal scales, the non-parametric test Spearman's rho is used instead of Pearson Correlation test to evaluate the correlation between CGPA and Satisfaction Index. Spearman's rho coefficient is 0.095 and it is significant at 0.01 level (from Table 7). This showed that there is a weak but significant correlation between CGPA and Satisfaction Index. The test being significant could possibly be due to the large sample size of 880 .

Table 7

Correlation Test between of CGPA and Satisfaction Index

\begin{tabular}{lllll}
\hline & & CGPA & Satisfaction Index \\
\hline Spearman's rho & CGPA & Correlation Coefficient & 1.000 & $.095^{* *}$ \\
& & Sig. (2-tailed) &. & .005 \\
& N & 880 & 880 \\
& \multirow{2}{*}{ Satisfaction Index } & Correlation Coefficient & $.095^{* *}$ & 1.000 \\
& Sig. (2-tailed) & .005 &. \\
& $\mathrm{~N}$ & 880 & 880 \\
\hline
\end{tabular}

Note. ${ }^{* *}$. Correlation is significant at the 0.01 level (2-tailed)

From Qn 4 and Qn 5 of the survey items as shown in Table 8 below, this study would generally assume that Qn 4 pertained to the negative experiences they might had in their learning, while Qn 5 pertained to the positive learning experiences of learning. Both items were perceived to have the ability to affect the satisfaction level of the students in their learning in the university since personal learning experiences dictated the student satisfaction level.

\section{Table 8}

Questionnaire Item 4 and 5

\begin{tabular}{|l|c|}
\hline \multicolumn{1}{|c|}{ Questionnaire Item } & \multicolumn{1}{c|}{ Response } \\
\hline Q4: In what ways could your learning experience be enhanced/improved? & \multirow{2}{*}{ OPEN ENDED RESPONSE } \\
\cline { 1 - 2 } Q5: What did you like best about your learning experience? & \\
\hline
\end{tabular}

The analysis, through the process of coding and categorization, in Khiat (2013), showed that the students' learning experiences (that could affect their satisfaction level) in terms of Qn 4 and Qn 5 could be generally 
The relationship between learning satisfaction and academic achievement of non-traditional learners categorized into three main categories of student perception related to: a) Instructors; b) Learning resources and c) Non learning related factors:

$>$ The category of Instructor related factors is related to areas pertaining to desirable lecturer/tutor characteristics that can affect the effective delivery of lessons - a) Content/Application Knowledge, b) Pedagogical Knowledge, c) Support of Student Learning, d) Commitment to Teaching and e) Empathy towards Student Needs.

$>\quad$ Learning resources are related to five areas - a) Course Delivery, b) Assignments, c) Learning Materials, d) Learning Space and e) Exams

$>\quad$ Non learning related issues are related to five areas - a) Administration, b) Operation, c) Transport, d) Food and Beverages and e) General Facilities.

The two tables (Table 9 and Table 10) below showed the frequency counts of each of the categories in Qn 4 and Qn 5 respectively.

Table 9

Frequency Count for Questionnaire Item 4

\begin{tabular}{llllll}
\hline & Frequency & Percent & Valid Percent & Cumulative Percent \\
\hline Valid & Nil & 261 & 29.7 & 29.7 & 29.7 \\
& Instructors & 131 & 14.9 & 14.9 & 44.5 \\
& Learning Resources & 350 & 39.8 & 39.8 & 84.3 \\
& Non Learning Related & 138 & 15.7 & 15.7 & 100.0 \\
& Total & 880 & 100.0 & 100.0 & \\
\hline
\end{tabular}

Table 10

Frequency Count for Questionnaire Item 5

\begin{tabular}{llllll}
\hline & Frequency & Percent & Valid Percent & Cumulative Percent \\
\hline Valid & Nil & 309 & 35.1 & 35.1 & 35.1 \\
& Instructors & 196 & 22.3 & 22.3 & 57.4 \\
& Learning Resources & 74 & 8.4 & 8.4 & 65.8 \\
& Non Learning Related & 301 & 34.2 & 34.2 & 100.0 \\
& Total & 880 & 100.0 & 100.0 & \\
\hline
\end{tabular}

A Chi square test for independence is conducted to test if there is a significant relationship between the factors identified above and the learner Satisfaction Index. In this case, the learner Satisfaction Index is re-categorized into three groups - Unsatisfied (Score 1-2), Neutral (Score 3) and Satisfied (Score 4-5). By doing that, a clearer and more distinct categorization of satisfaction level is created.

Table 11 and Figure 3 below are the cross tabulation and histogram between the Satisfaction Index and number of negative comments respectively. From the statistics, it was shown that $96.7 \%$ of the respondents in the "Unsatisfied" group made negative comments about their learning experience as compared to $92.5 \%$ of those in the "Neutral" group and $61.9 \%$ of those in the "Satisfied" group. This set of statistics is reasonable taking in account that unsatisfied students tend to have more to complain, than compliment, about their learning experience.

Table 12 reported that the chi-square test was statistically significant, $\chi^{2}(6, \mathrm{~N}=880)=97.477, \mathrm{p}<0.001$, indicating that there was an significant association between the level of Satisfaction Index and the type of negative comments made in terms of their learning experience. The effect size of this association is small at $\varphi=$ 0.235 as reported by Cramer's V in Table 13. In terms of the nature of their negative comments, the majority of all three groups, $63.3 \%, 52.3 \%$ and $34.2 \%$ of the respondents in the "Unsatisfied", "Neutral" and "Satisfied" group made negative comments about learning resources. Negative comments about learning resources are 
Khiat, H.

related to five areas - a) Course Delivery, b) Assignments, c) Learning Materials, d) Learning Space and e) Exams.

\section{Table 11}

Satisfaction Index * Qn 4 cross tabulation

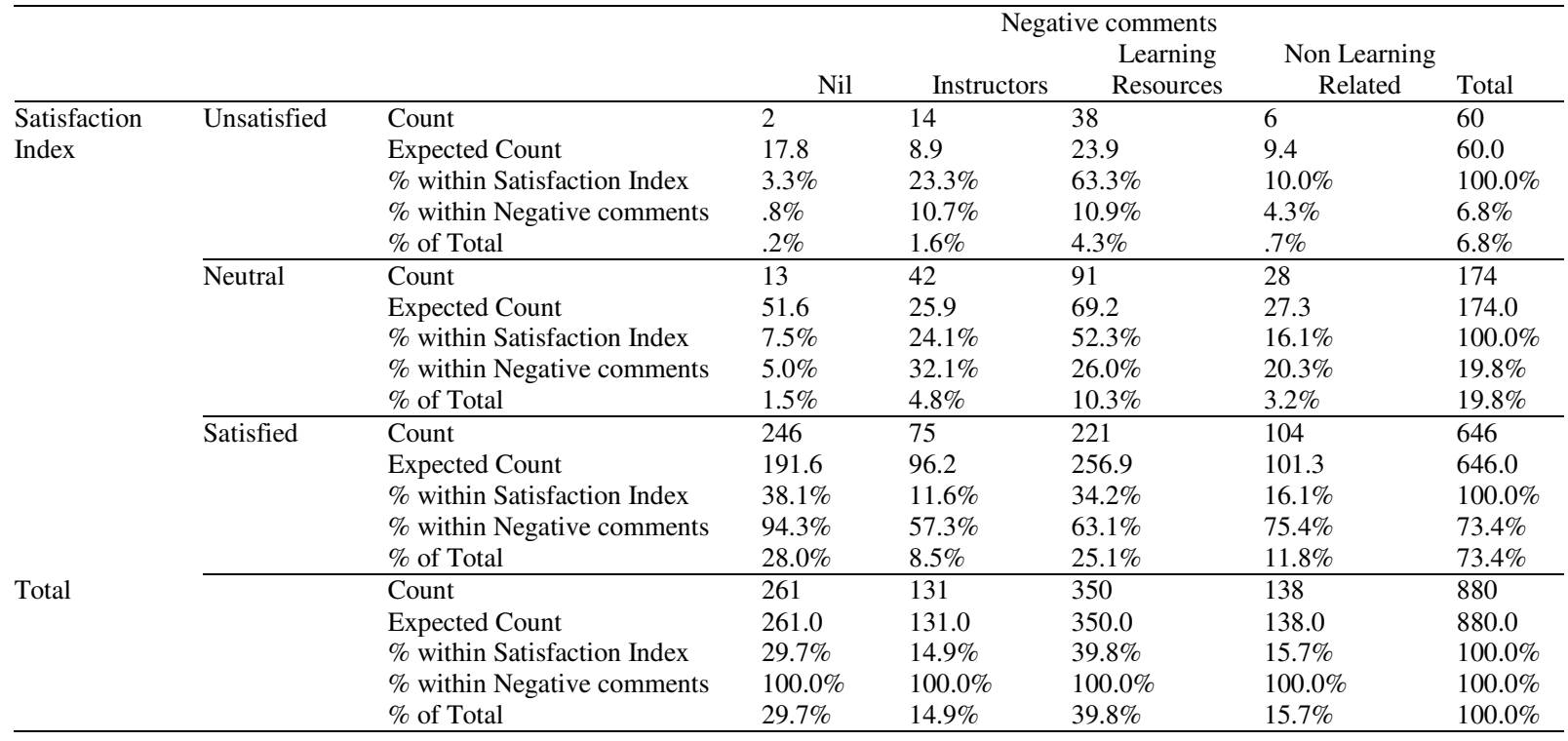

Figure 3. Satisfaction index against type of negative comments

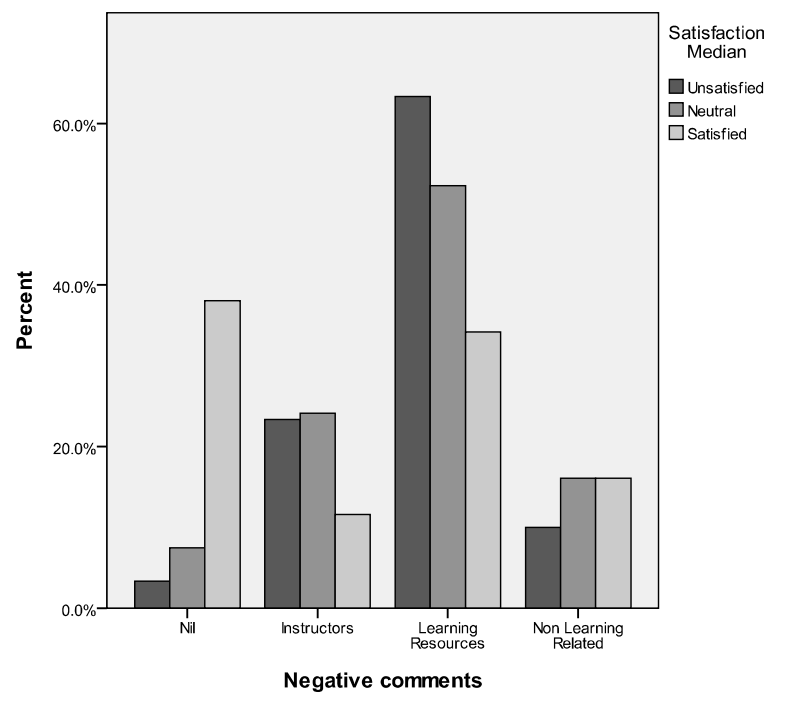

Table 12

Chi Square Test for Qn 4

\begin{tabular}{llll}
\hline & Value & df & Asymp. Sig. (2-sided) \\
\hline Pearson Chi-Square & $97.477^{\text {a }}$ & 6 & .000 \\
Likelihood Ratio & 114.385 & 6 & .000 \\
Linear-by-Linear Association & 32.129 & 1 & .000 \\
N of Valid Cases & 880 & & \\
\hline
\end{tabular}

Note. a. 0 cells (.0\%) have expected count less than 5. The minimum expected count is 8.93

Table 13

Symmetric Measures for Qn 4

\begin{tabular}{llll}
\hline & & Value & Approx. Sig. \\
\hline Nominal by Nominal & Phi & .333 & .000 \\
& Cramer's V & .235 & .000 \\
N of Valid Cases & & 880 & \\
\hline
\end{tabular}


The relationship between learning satisfaction and academic achievement of non-traditional learners

This set of statistics is reasonable taking in account that unsatisfied students tend to have more to complain about. In terms of the nature of their negative comments, 63.3\%, 52.3\% and $34.2 \%$ of the respondents (highest percentage in each group) in the "Unsatisfied", "Neutral" and "Satisfied" groups unanimously made negative comments about learning resources respectively. Negative comments about learning resources are related to five areas - a) Course Delivery, b) Assignments, c) Learning Materials, d) Learning Space and e) Exams.

Table 14 and Figure 4 below are the cross tabulation and histogram between the Satisfaction Index and number of positive comments respectively. From the statistics, it was shown that $80.0 \%$ of the respondents in the "Unsatisfied" group did not made any positive comments about their learning experience as compared to $60.9 \%$ of those in the "Neutral" group and $24.0 \%$ of those in the "Satisfied" group. This set of statistics is reasonable taking in account that unsatisfied students tend to have less to compliment about their learning experience.

\section{Table 14}

Satisfaction Index * Qn 5 cross tabulation

\begin{tabular}{|c|c|c|c|c|c|c|c|}
\hline & & & \multicolumn{5}{|c|}{ Positive comments } \\
\hline & & & Nil & Instructors & $\begin{array}{l}\text { Learning } \\
\text { Resources }\end{array}$ & \multicolumn{2}{|c|}{ Non Learning } \\
\hline Satisfaction & Unsatisfied & Count & 48 & 4 & 3 & 5 & 60 \\
\hline \multirow{8}{*}{ Index } & & $\%$ within Satisfaction Index & $80.0 \%$ & $6.7 \%$ & $5.0 \%$ & $8.3 \%$ & $100.0 \%$ \\
\hline & & $\%$ within Positive comments & $15.5 \%$ & $2.0 \%$ & $4.1 \%$ & $1.7 \%$ & $6.8 \%$ \\
\hline & & $\%$ of Total & $5.5 \%$ & $.5 \%$ & $.3 \%$ & $.6 \%$ & $6.8 \%$ \\
\hline & & $\%$ within Satisfaction Index & $60.9 \%$ & $17.2 \%$ & $6.9 \%$ & $14.9 \%$ & $100.0 \%$ \\
\hline & & $\%$ within Positive comments & $34.3 \%$ & $15.3 \%$ & $16.2 \%$ & $8.6 \%$ & $19.8 \%$ \\
\hline & & $\%$ of Total & $12.0 \%$ & $3.4 \%$ & $1.4 \%$ & $3.0 \%$ & $19.8 \%$ \\
\hline & Satisfied & Count & 155 & 162 & 59 & 270 & 646 \\
\hline & & Expected Count & 226.8 & 143.9 & 54.3 & 221.0 & 646.0 \\
\hline \multirow{4}{*}{ Total } & & Expected Count & 309.0 & 196.0 & 74.0 & 301.0 & 880.0 \\
\hline & & $\%$ within Satisfaction Index & $35.1 \%$ & $22.3 \%$ & $8.4 \%$ & $34.2 \%$ & $100.0 \%$ \\
\hline & & $\%$ within Positive comments & $100.0 \%$ & $100.0 \%$ & $100.0 \%$ & $100.0 \%$ & $100.0 \%$ \\
\hline & & $\%$ of Total & $35.1 \%$ & $22.3 \%$ & $8.4 \%$ & $34.2 \%$ & $100.0 \%$ \\
\hline
\end{tabular}
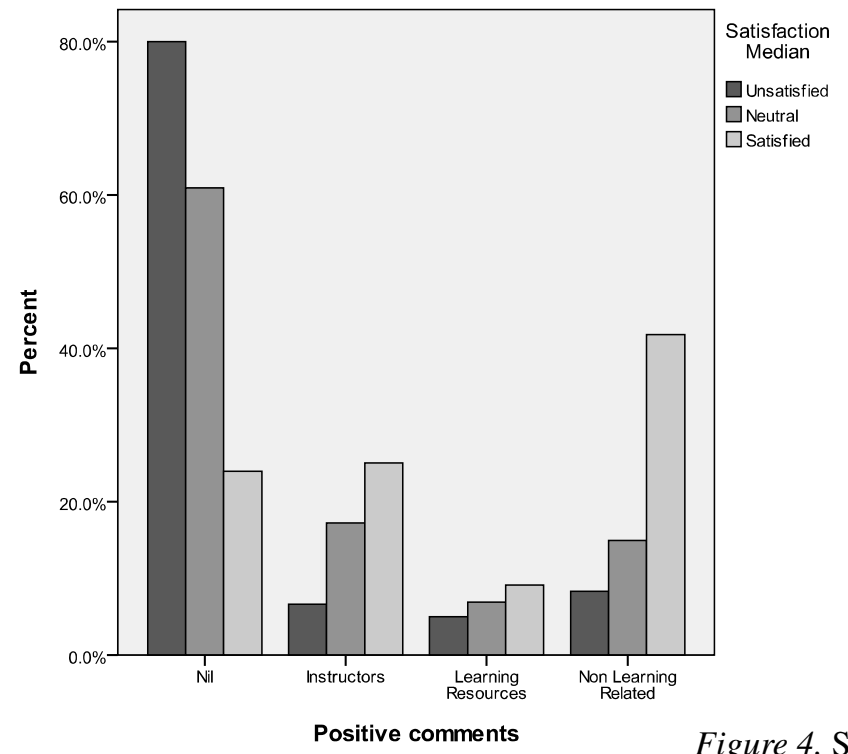

Figure 4. Satisfaction index against type of positive comments

Table 15 reported that the chi-square test was statistically significant, $\chi 2(6, \mathrm{~N}=880)=144.200, \mathrm{p}<0.001$, indicating that there was an significant association between the level of Satisfaction Index and the type of positive comments made in terms of their learning experience. The effect size of this association is small at $\varphi=$ 
Khiat, H.

0.286 as reported by Cramer's V in Table 16. In terms of the nature of their positive comments, the majority in the "Satisfied" group, $41.8 \%$ of the respondents made positive comments about non learning related issues. Positive comments about non learning related issues are related to five areas - a) Administration, b) Operation, c) Transport, d) Food and Beverages, and e) General Facilities. These factors are presumed to have lesser impact on student learning than the other two categories of learning resources and instructors. In the "Neutral" group, $17.2 \%$ and $14.9 \%$ of the respondents made positive comments about instructors and non-learning related issues. Positive comments about instructors are related to areas pertaining to desirable lecturer/tutor characteristics that can affect the effective delivery of lessons. They are a) Content/Application Knowledge, b) Pedagogical Knowledge, c) Support of Student Learning, d) Commitment to Teaching and e) Empathy towards Student Needs. As for the "Unsatisfied" group, there is no clear indication which area they made positive comments substantially as the percentages for the three categories of comments are comparable.

\section{Table 15}

Chi Square Test for Qn 5

\begin{tabular}{llll}
\hline & Value & df & Asymp. Sig. (2-sided) \\
\hline Pearson Chi-Square & $144.200^{\mathrm{a}}$ & 6 & .000 \\
Likelihood Ratio & 144.141 & 6 & .000 \\
Linear-by-Linear Association & 106.850 & 1 & .000 \\
N of Valid Cases & 880 & & \\
\multicolumn{2}{l}{ Note. a. 0 cells (.0\%) have expected count less than 5. The minimum expected count is 5.05 }
\end{tabular}

Table 16

Symmetric Measures for Qn 5

\begin{tabular}{llll}
\hline & & Value & Approx. Sig. \\
\hline Nominal by Nominal & Phi & .405 & .000 \\
& Cramer's V & .286 & .000 \\
N of Valid Cases & & 880 & \\
\hline
\end{tabular}

\section{Discussion}

In addition to giving a brief overview of learning satisfaction experienced by traditional and non-traditional learners, this paper showed that, in the context of this study, the correlation between learning satisfaction and academic achievement is weak for non-traditional learners. And it is supported by the next level of analysis which categorised learning satisfaction in three different domains-: a) Instructors; b) Learning resources and c) Non learning related factors. The category of Instructor related factors is related to areas pertaining to desirable lecturer/tutor characteristics that can affect the effective delivery of lessons - a) Content/Application Knowledge, b) Pedagogical Knowledge, c) Support of Student Learning, d) Commitment to Teaching and e) Empathy towards Student Needs. Learning resources are related to five areas - a) Course Delivery, b) Assignments, c) Learning Materials, d) Learning Space and e) Exams while non-learning related issues are related to five areas a) Administration, b) Operation, c) Transport, d) Food and Beverages and e) General Facilities. These three derived domains are similar to those categories of learning satisfaction developed in the studies by Aman (2009), Beqiri, Chase, and Bishka (2010), Betz, Klingensmith, and Menne (1970), Calaguas (2012), Corts, Lounsbury, Saudargas, and Tatum (2000) and Kara (2004). Interestingly, there was no mention of academic achievement or underachievement in the comments pertaining to Qn4 and Qn 5, further strengthening the conclusion made in this study that pointed to the weak relationship between learning satisfaction and academic achievement.

This perceived weak relationship is not in total congruence with the conclusion that the level of learning effectiveness would then be translated to the level of academic development or grade achieved by a learner as proposed by Centra and Rock (1983), Hatcher et al. (1992), Pike (1991), and Umbach and Porter (2002). In the context of adult learners in the case university, this study has shown that learning satisfaction is weakly related to academic results. This perceived weak relationship could possibly mean that non-traditional learners do not derive their learning satisfaction from good academic results. However, this explanation might seem to be 
The relationship between learning satisfaction and academic achievement of non-traditional learners

farfetched in normal circumstances where academic certification is an important step up the social and financial ladder in the society. Seeing this phenomenon from another perspective, it might be more reasonable to conclude that this study was done in an Asian context and the value of humility and shame did not allow them to flaunt their academic achievement or complain about their academic deficiency respectively in a sanctioned questionnaire survey. In another way, it could also be hypothesized that learning satisfaction is no longer related to academic grades as academic endeavors become such a competitive and pressurizing trial in the Singapore context that students generally could not get any good feelings of satisfaction from academic achievement.

Regardless of the weak relationship between learning satisfaction and academic achievement, there are a number of practical implications at both policy-making level and classroom level due to the uncovering of the three domains of learning satisfaction and their relationships. First of all, it is important that the policy makers relook more in depth and width in the real reasons behind the perceived weak relationship. While this relook is important, policy makers will not be starting from ground zero as this study also uncovered the relationship between low learning satisfaction could be generally related to the area of learning resources in five areas - a) Course Delivery, b) Assignments, c) Learning Materials, d) Learning Space and e) Exams. These five areas could serve as a good starting point to address the issues of low learning satisfaction in the case university.

For the instructors in the case university, it too has implications on how they can enhance the learning experience of their students through providing the various components of the instructor domain as uncovered in this study is found to have an effect on student learning satisfaction: a) Content/Application Knowledge, b) Pedagogical Knowledge, c) Support of Student Learning, d) Commitment to Teaching and e) Empathy towards Student Needs. For the students in the case university, this study allows them to understand what they and their peers perceived as learning satisfaction in their study journey. Such awareness can help the students to manage their expectations in learning better.

\section{Conclusion}

This paper had answered its research question, "What are the relationships between non-traditional learner satisfaction level in learning, their academic performance and the identified influencing factors of learning satisfaction?" The analysis showed that there is a weak correlation between academic achievement and learning satisfaction and low learning satisfaction usually arose because of the deficiency in the provision of learning resources to the students. Notwithstanding that, the paper had to acknowledge that the analysis might not be in depth and width enough to provide more illuminating and accurate results due to the limitation posed by the type of collected data that was designed by the case university and was not conceptualized by the researcher.

In conclusion, understanding how learning satisfaction originated from non-traditional learners in the case university is important as the case university can focus on addressing them as a starting point to improve their learning satisfaction which can impact on student learning. It has also helped the instructors and students to understand how learning satisfaction is conceptualized from the perspectives of non-traditional learners. At the same time, from a research viewpoint, this study can contribute to the existing relevant literature related to learning satisfaction of non-traditional learners.

\section{References}

Aldridge, S., \& Rowley, J. (1998). Measuring student satisfaction in higher education, Quality Assurance in Education, 6(4), 197-204. http://dx.doi.org/10.1108/09684889810242182

Aman, R. R. (2009). Improving student satisfaction and retention with online instruction through systematic faculty peer review of courses. Unpublished doctoral dissertation. Oregon State University. AAT 3376735 .

Beqiri, M. S., Chase, N. M., \& Bishka, A. (2010). Online course delivery: An empirical investigation of factors affecting student satisfaction. Journal of Education for Business, 85(2), 95-100. 
Khiat, $\mathrm{H}$.

http://dx.doi.org/10.1080/08832320903258527

Betz, E. L., Klingensmith, J. E., \& Menne, J. W. (1970). The measurement and analysis of college student satisfaction. Measurement and Evaluation in Guidance, 3, 110-118.

Bontenbal, K. (2000). Challenges faced by reference librarians in familiarization of adult students with the computerized library of today: The Cuesta College experience. The Reference Librarian, 70, 69-76. http://dx.doi.org/10.1300/J120v33n69_07

Brown, J. (2004). Marketing and retention strategies for adult degree programs. New Directions for Adult and Continuing Education, 103, 51-60. http://dx.doi.org/10.1002/ace.148

Bull, K., \& Kimball, S. (2000). Teaching adult (nontraditional) learners in computer mediated learning. Retrieved from http://home.okstate.edu/homepages.nsf/toc/EPSY5720cml60

Calaguas, G. M. (2012). Teacher effectiveness scale in higher education: Development and psychometric properties. International Journal of Research Studies in Education, 2(2), 3-20. http://dx.doi.org/10.5861/ijrse.2012.108

Centra, J. A., \& Rock, D. (1983). College environments and student achievement. American Educational Research Journal, 8, 623-634. http://dx.doi.org/10.3102/00028312008004623

Compton, J. I., Cox, E., \& Laanan, F. S. (2006). Adult learners in transition. New Directions for Student Services, 114, 73-80. http://dx.doi.org/10.1002/ss.208

Corts, D. P., Lounsbury, J. W. Saudargas, R. A.,\& Tatum, H. E. (2000). Assessing undergraduate satisfaction with an academic department: A method and case study. College Student Journal, 34(3), 399-410.

Elliott, K. M., \& Shin D. (2002) Student Satisfaction: an alternative approach to assessing this important concept, Journal of Higher Education Policy and Management, 24(2), 199-209. http://dx.doi.org/10.1080/1360080022000013518

Emery, C., Kramer, T., \& Tian, R. (2001) Customer vs. products adopting an effective approach to business students. Quality Assurance in Education, 9(2), 110-115. http://dx.doi.org/10.1108/09684880110389681

Eyck, R., Tews, M., \& Ballester, J. M. (2009). Improved medical student satisfaction and test performance with a simulation-based emergency medicine curriculum: A randomized controlled trial. ACEP 2008 Research Forum, October 2008, Chicago, IL.

Gray, B. J., Fam, K. S., \& Llanes, V. A. (2003). Branding universities in Asian markets, Journal of Product \& Brand Management, 12(2), 108-120. http://dx.doi.org/10.1108/10610420310469797

Guolla, M. (1999). Assessing the teaching quality to student satisfaction relationship: applied customer satisfaction research in the classroom, Journal of Marketing Theory \& Practice, 7(3), 87-96.

Hadfield, J. (2003). Recruiting and retaining adult students. New Directions for Student Services, 102, 17-25. http://dx.doi.org/10.1002/ss.85

Hatcher, L., Kryter, K., Prus, J., \& Fitzgerald, V. (1992). Predicting college student satisfaction, commitment, and attrition from invest model constructs. Journal of Applied Social Psychology, 22, 1273 - 1296. http://dx.doi.org/10.1111/j.1559-1816.1992.tb00950.x

Howell, C. L. (2001). Facilitating responsibility for learning in adult community college students. Washington, D. C. Office of Educational Research and Improvement.

Jamelske, E. (2009). Measuring the impact of a university first-year experience program on student GPA and retention. Higher Education, 57(3), 373-391. http://dx.doi.org/10.1007/s10734-008-9161-1

Kara, A. (2004). Business student satisfaction, intentions and retention in higher education: An empirical investigation. $M E Q, 3,1-15$.

Keith, P. (2007). Barriers and non-traditional students' use of academic and social services, College Student Journal, 41(4), 1123-1127.

Kotler, P., Lane, K. K., Koshy, A., \& Jha, M. (2009). Marketing Management - A South Asian perspective. Pearson Publication.

Khiat, H. (2013). Conceptualisation of learning satisfaction experienced by non-traditional learners in Singapore. e-Journal of Educational Research, 2(2), 92-106.

Malin, J., Bray, J., Dougherty, T., \& Skinner, W. (1980). Factors affecting the performance and satisfaction of adult men and women attending college. Research in Higher Education, 13, 115-130. 
The relationship between learning satisfaction and academic achievement of non-traditional learners http://dx.doi.org/10.1007/BF00977627

Marsh, H. W., \& Roche, L. A. (1997). Making students' evaluations of teaching effectiveness effective: The critical issues of validity, bias and utility. American Psychologist, 52(11), 1187-1197. http://dx.doi.org/10.1037/0003-066X.52.11.1187

Martin CL (1988). Enhancing children's satisfaction and participation using a predictive regression model of bowling performance norms. The Physical Educator, 45(4), 196-209.

Noel-Levitz, Inc. (2009). The national adult student priorities report. Coralville, IA: Noel- Levitz, Inc.

Özgüngör, S. (2010). Identifying dimensions of students' ratings that best predict students' self-efficacy, course value and satisfaction. Eurasian Journal of Educational Research, 38, 146-163.

Pike, G. R. (1991). The Effects of background, coursework, and involvement on students' grade and satisfaction. Research in Higher Education, 32(1), 15-31. http://dx.doi.org/10.1007/BF00992830

Spady, W. (1970). Dropouts from higher education: An interdisciplinary review and synthesis. Interchange, I, 64-85. http://dx.doi.org/10.1007/BF02214313

Sweeney, J. C., \& Ingram, D. (2001). A comparison of traditional and web marketing education: An exploratory study. Journal of Marketing Education, 23(1), 55-62. http://dx.doi.org/10.1177/0273475301231007

Tough, A. (1982). Some major reasons for learning. (ERIC Document Reproduction Service No. ED033251)

Umbach, P. D., \& Porter, S. R. (2002). How do academic departments impact student satisfaction? Understanding the contextual effects of departments. Research in Higher Education, 43(2), 209-233. http://dx.doi.org/10.1023/A:1014471708162

Upcraft, M. L., \& Schuh, J. H. (1996). Assessment in student affairs: A guide for practitioners. San Francisco: Jossey-Bass.

Vander Zanden, J. (2000). Human development. (7th ed.) Boston: McGraw-Hill Higher Education.

Wei, F. W. (2007). Teaching above and beyond traditional students' needs: A comparison between traditional and non-traditional college students' expectations of classroom communication. International Communication Association, San Francisco, CA.

Wiers-Jenssen, J., Stensaker, B., \& Grogaard, J. B. (2002). Student datisfaction: Towards an empirical deconstruction of the concept. Quality in Higher Education, 8(2), 183-195. http://dx.doi.org/10.1080/1353832022000004377

Wintre, M. G., \& Yaffe, M. (2000). First-year student adjustment to university life as a function of relationships with parents. Journal of Adolescent Research, 15(1), 29-37. http://dx.doi.org/10.1177/0743558400151002

Witowski, L. (2008). The relationship between instructional delivery methods and students learning preferences: What contributes to students' satisfaction in an online learning environment? Unpublished doctoral dissertation. Retrieved on December 11, 2010 from http://gradworks.umi.com/3310726.pdf 
Khiat, $\mathrm{H}$. 